Retraction of:

\title{
Cerebrospinal fluid monoamine metabolites in Huntington dementia, movement disorders, and normal aging
}

\author{
Stephen M. Stahl, MD, PhD \\ Kym F. Faull, PhD \\ Jack D. Barchas, MD \\ Philip A. Berger, MD \\ From the Mental Health Clinical Research Center, \\ Stanford University, \\ and the Palo Alto Veterans Administration Hospital \\ Presented at the 35th Annual Meeting \\ of the American Academy of Neurology, \\ San Diego, California, April 1983.
}

Published as an Abstract in Neurology 1983;33(Suppl 2):218

\section{Note from the Editor-in-Chief:}

The retraction of this abstract follows the report of the Panel to Investigate Possible Misconduct in Science under Grant MH-30854 (Stanford University Mental Health Clinical Research Center) to the Deputy Director of the National Institute of Mental Health. The Panel deemed the reported results invalid because of methodological and procedural flaws in the study.

The form of this retraction complies with the recommendations of the International Committee of Medical Journal Editors (Annals of Internal Medicine 1988;108:304.) 


\section{Neurology}

\section{Retraction of: Cerebrospinal fluid monoamine metabolites in Huntington dementia, movement disorders, and normal aging}

Stephen M. Stahl, Kym F. Faull, Jack D. Barchas, et al.

Neurology 1989;39;1261

DOI 10.1212/WNL.39.9.1261

This information is current as of September 1, 1989

Updated Information \&

Services

Permissions \& Licensing

Reprints including high resolution figures, can be found at:

http://n.neurology.org/content/39/9/1261.citation.full

Information about reproducing this article in parts (figures,tables) or in its entirety can be found online at:

http://www.neurology.org/about/about_the_journal\#permissions

Information about ordering reprints can be found online:

http://n.neurology.org/subscribers/advertise

Neurology $®$ is the official journal of the American Academy of Neurology. Published continuously since 1951, it is now a weekly with 48 issues per year. Copyright (C) 1989 by AAN Enterprises, Inc.. All rights reserved. Print ISSN: 0028-3878. Online ISSN: 1526-632X.

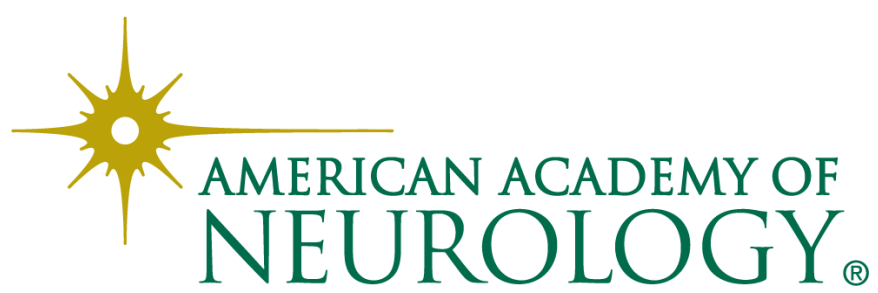

